\title{
SPATIAL VARIABILITY OF YIELD AND OTHER PARAMETERS ASSOCIATED WITH PEAR TREES
}

\section{MARCIA R. S. KONOPATZKI ${ }^{1}$, EDUARDO G. SOUZA ${ }^{2}$, LÚCIA H. P. NÓBREGA ${ }^{3}$, MIGUEL A. URIBE-OPAZO ${ }^{4}$, GRAZIELI SUSZEK ${ }^{5}$}

\begin{abstract}
In the last few years, precision agriculture has become commonly used with many crops, particularly cereals, and there is also interest in precision horticulture. Pear is a seasonal fruit and well appreciated by Brazilian people, although it is mostly imported. Brazilian farmers are nowadays trying to increase pear production. Thus, this research aimed at mapping the yield of pear trees in order to study the spatial variability of yield as well as its comparison with spatial variability of soil and plant attributes. The experimental field had 146 pear trees, variety 'Pêra d'água', distributed on a 1.24 ha. Four harvests were performed according to the fruit ripening and from each tree; only the ripe fruits were harvested. In each harvest, all the fruits were weighed and the total yield was obtained based on the sum of each harvest. The soil attributes analyzed were $\mathrm{P}$, $\mathrm{K}, \mathrm{Ca}, \mathrm{Mg}, \mathrm{pH}$ in $\mathrm{CaCl}_{2}, \mathrm{C}, \mathrm{Cu}, \mathrm{Zn}, \mathrm{Fe}, \mathrm{Mn}$ and base saturation, and the plant attributes were fruit length, diameter and yield. Yield had low correlation with soil and plant attributes. An index of spatial variability was suggested in this study and helped in classifying levels of spatialdependence of the various soil and plant attributes: very low (fruit length); low (P, fruit diameter), medium (Mg, $\mathrm{pH}, \mathrm{Cu}, \mathrm{Zn}, \mathrm{Fe})$, high ( $\mathrm{Ca}, \mathrm{K}$, base saturation and yield), and very high ( $\mathrm{Mn}$ and $\mathrm{C})$.
\end{abstract}

KEYWORDS: precision agriculture, thematic maps, horticulture.

\section{VARIABILIDADE ESPACIAL D A PRODUTIVIDADE E OUTROS PARÂMETROS ASSOCIADOS COM PÉS DE PERA}

RESUMO: Nos últimos anos, a agricultura de precisão tornou-se comumente utilizada em muitas culturas, particularmente cereais, mas há também interesse em fruticultura de precisão. Pera é uma fruta sazonal e muito apreciada no Brasil, apesar de ser principalmente importada. Agricultores brasileiros estão atualmente tentando aumentar a produção de peras. Assim, esta pesquisa visou mapear a produtividade de pés de peras com o objetivo de estudar sua variabilidade assim como relacionar a variabilidade espacial dos atributos do solo e da planta. A área experimental tem 146 pés de pera, variedade Pera-d'água, distribuída em uma área de 1,24 ha. Quatro colheitas foram realizadas de acordo com a maturação da fruta e somente as frutas maduras de cada pé foram colhidas. Em cada colheita, todas as frutas foram pesadas, e a produtividade foi obtida baseada na soma de cada colheita. Os atributos do solo analisados foram $\mathrm{P}, \mathrm{K}, \mathrm{Ca}, \mathrm{Mg}, \mathrm{pH}$ em $\mathrm{CaCl}_{2}, \mathrm{C}, \mathrm{Cu}$, $\mathrm{Zn}, \mathrm{Fe}, \mathrm{Mn}$ e saturação de bases, e os atributos da planta foram comprimento e diâmetro do fruto e produtividade. A produtividade teve baixa correlação com os atributos do solo e da planta. Um índice de variabilidade espacial foi proposto neste estudo e auxiliou na classificação dos níveis de dependência espacial de diferentes atributos do solo e da planta: muito baixo (comprimento de fruta); baixo ( $\mathrm{P}$, diâmetro do fruto); médio ( $\mathrm{Mg}, \mathrm{pH}, \mathrm{Cu}, \mathrm{Zn}$ e $\mathrm{Fe}$ ), alto (Ca, K, saturação de base e produtividade) e muito alto (Mn e C).

PALAVRAS-CHAVE: agricultura de precisão, mapas temáticos, fruticultura.

\footnotetext{
${ }^{1}$ Eng a A grícola, Pós-Graduanda da UNIOESTE/CASCA VEL/CCET/PGEAGRI/SBA, Grupo de Pesquisa GROSAP, Cascavel - PR, mae_agricola@y ahoo.com.br. Bolsista da CAPES.

${ }^{2}$ Eng ${ }^{2}$ Mecânico, Prof. Associado da UNIOESTE/CASCAVEL/CCET/PGEAGRI/SBA, Grupos de Pesquisa GROSAP e GGEA, Cascavel - PR, eduardo.souza@unioeste.br. Pesquisador de Produtividade do CNPq.

${ }^{3}$ Eng a Agronoma, Profa. Associada da UNIOESTE/CA SCAVEL/CCET/PGEAGRI/SBA, Grupos de Pesquisa GROSAP e GGEA, Cascavel - PR, lu cia.nobrega@ unioeste.br. Pesquisador de Produtividade do CNPq.

${ }^{4}$ Estatístico, Prof. Associado da UNIOESTE/CASCAVEL/CCET/PGEAGRI/SBA, Grupos de Pesquisa GROSAP e GGEA, PR, miguel.opazo@unioeste.br. Pesquisador de Produtividade do CNPq.

${ }^{5}$ Eng ${ }^{\mathrm{a}}$ A grícola, Profa. EBTT Instituto Federal do Mato Grosso do Sul (IFMS) - Nova Andradina - MS, grazieli.suszek@ifms.edu.br. Recebido pelo Conselho Editorial em: 16-5-2011

Aprovado pelo Conselho Editorial em: 9-11-2011
} 


\section{INTRODUCTION}

Precision agriculture (PA) is the management of agricultural production according to the characteristics and needs of small production units. Sometimes these units may be based on a single plant or animal. PA aims to improve the use of inputs, thus increasing profit for farmers and preserving environmental quality. This practice has several steps, including data collection, management planning and site-specific application of agricultural inputs.

During data collection, the objective is to identify the variability of production factors, as well as of cropping in the field. Usually a yield map is created to visualize spatial variability. However, this map is only one of the steps involved in the whole PA process and represents the combined effect of several sources of spatial and temporal variability. Part of this variability can be attributed to constant factors or to factors which vary slowly. Others are transitory, changing in their importance and/or spatial and temporal distributions from one season to another.

Pear is one of the favorite seasonal fruits in Brazil, but most are imported. In 2005, Brazil produced approximately 16,000 metric tons of pear, in an area of 1,760 ha, while the world production was 20 million tons. In 2007, Brazilian pear imports reached 103,000 tons (FIORAVANÇO, 2007). Therefore, pear production is an attractive agricultural alternative to farmers of the Brazilian Southern Region, which is edaphically and climatically prepared for such a crop. Only apple production is more economically advantageous than pear production in this region.

Although the majority of Brazilian and worldwide researches in PA are applied to grain crops, some researches in horticulture have already been published. In Brazil, FARIAS et al. (2003), MOLIN \& MASCARIN (2007), LEÃO et al. (2010), and SIQUEIRA et al. (2010) worked with citrus; SILVA et al. (2007), with coffee; CALDERON et al. (2008), with mango; and MIRANDA et al. (2005), with melon. Internationally, AGGELOPOULOU et al. (2010a, b, c) worked with apples; TISSEYRE \& Mcbratney (2008) with grapevine; and PERRY et al. (2009) with pear.

In addition to the lack of knowledge of the root system and of specific fertilizer application techniques, defined criteria for the better recommendation of inputs in perennial plants do not exist yet. The fruit trees explore large soil volumes and they differ from annual plants because the ir roots, stems, and branches can store nutrients from one year to the next. Generally, attempts to correlate values from soil analysis with the nutrient needs of perennial plants have not been successful. This probably happens because it is almost impossible to collect a sample to represent the soil mass explored by the roots and also because perennial plants have a different capacity for extracting nutrients from the soil than annual plants (FACHINELLO et al., 2008).

Therefore, this experiment mapped the yield of pear trees in order to analyze the spatial variability of yield, as well as to compare it with spatial variability of soil and plant attributes.

\section{MATERIAL AND METHODS}

The experimental area (Figure 1) is located in Nova Laranjeiras, State of Paraná, South of Brazil (25'23'22'S; 52³4'15'W; altitude $750 \mathrm{~m}$ ). The soil is classified as Distroferric Red Latossol (EMBRAPA, 1999) with $70 \%$ of clay. 


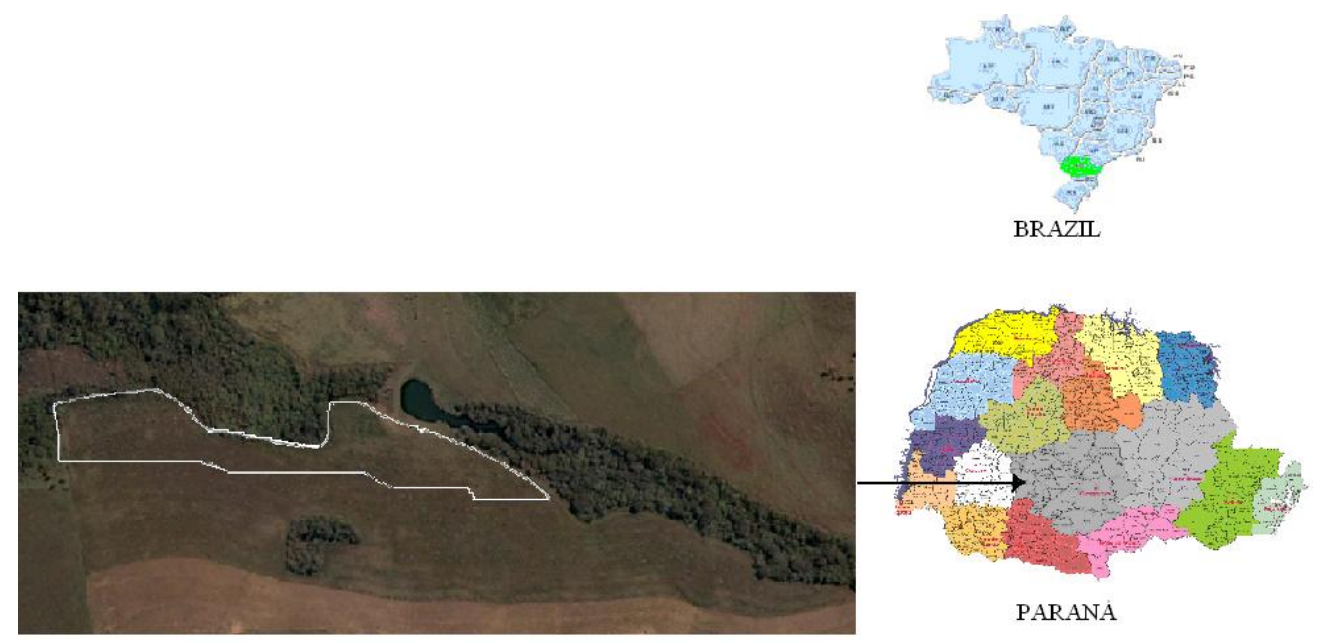

FIGURE 1. Image of the experimental area obtained with Google Earth 4.3 (2007).

For georeferencing (Figure 2), a Trimble Geo Explorer 3 Geodesic Differential Global Positioning System (GDGPS) with post-processing was used. The experimental area has 146 pear trees, distributed in a 1.24 ha and originally farmed under no-tillage with crops of corn, soybean, oats and sorghum. The orchard was established in 2000, using an $8 \mathrm{~m}$ distance between rows and $10 \mathrm{~m}$ between plants within the row. The pear variety "Kieffer" was used as rootstock upon which the pear variety "Pêra d'água" was grafted. In this study, yield data from the 2007 harvest was analyzed.

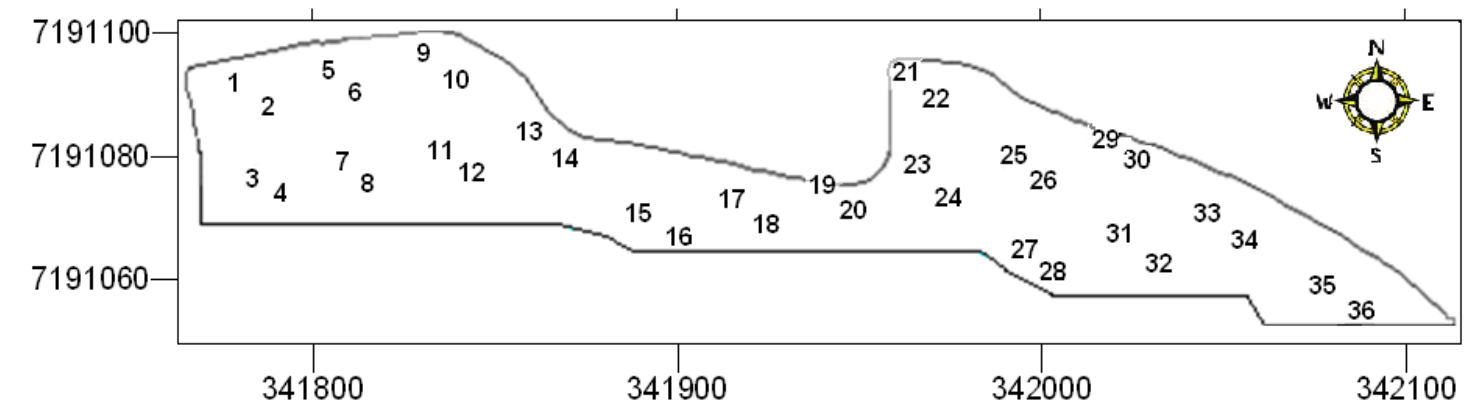

FIGURE 2. Spatial distribution of the pear trees used in the yield sampling in the experimental area (measurements in UTM).

At the orchard establishment, the soil of each planting hole was fertilized with phosphorus, lime and organic manure. Every subsequent year, additional fertilization with $\mathrm{N}$ and $\mathrm{P}$ was performed. The first harvest was accomplished on February 2006. Once Nova Laranjeiras, State of Paraná, is not considered climatically ideal to pear production, dormancy had to be chemically overcome to enable yield increases.

Four harvests were performed based on fruit maturation, and in each harvest, only the ripe fruits were picked, based on the farmer experience. The weight, diameter and length of fruits from 36 pear trees were computed and the total yield was then obtained by the sum of the individual yield of each plant (total weight). From these 36 trees, 18 were selected from a $30 \mathrm{~m}$ regular grid and the others 18 are the closest to these ones.

Soil samples were collected on a grid with a $30 \mathrm{~m}$ constant spacing and evaluated for $\mathrm{P}, \mathrm{K}$, $\mathrm{Cu}, \mathrm{Zn}, \mathrm{Fe}, \mathrm{Mn}, \mathrm{Ca}, \mathrm{Mg}, \mathrm{pH}$ (Calcium Chloride) and $\mathrm{C}$. The base saturation (V\%) were calculated. Each sample was composed of four sub-samples, randomly taken within one-meter radius. The sample depth was $20 \mathrm{~cm}$. Before data interpolation, the Pearson linear correlation coefficient (R) and the Spearman rank-order correlation coefficient $\left(\mathrm{R}_{\mathrm{S}}\right)$ were used to evaluate the extent of linear $(\mathrm{R})$ and non linear $\left(\mathrm{R}_{\mathrm{S}}\right)$ correlation among variables. In geostatistical analysis, semivariograms were 
built to verify the spatial dependence among samples. In order to estimate the structures of the experimental semivariance function, the classic Matheron estimator (variables with normal distribution) and Cressie and Hawkins estimator (non-normal distribution variables) were used. The extent of the semivariogram spatial dependence was evaluated using the spatial variability index (SVI, eq.(1)), proposed by the authors.

$$
\text { SVI }=\frac{\text { partial sill }}{\text { partial sill }+ \text { nugget effect }} 100
$$

where, partial sill and nugget effect are parameters of the semivariogram.

The $S V I$ classification proposed by the authors and adopted was: very low for $S V I<20 \%$; low for $20 \leq S V I<40 \%$; medium for $40 \leq S V I<60 \%$; high for $60 \leq S V I<80 \%$; and very high for $S V I>$ $80 \%$. This indicator is similar to the one proposed by CAMBARDELA et al. (1994), with the advantages of having five interpretation levels instead of three and being proportional to the spatial variability (the higher SVI the higher the spatial variability).

The Anderson-Darling and Kolmogorov-Smirnov tests were used to verify data normality at $5 \%$ probability. The data were considered normally distributed when fitting at least, one of the tests. Outliers were verified through box-plot graphs. The coefficient of variation (C.V.) was considered low when C.V. $\leq 10 \%$; medium when $10 \%<\mathrm{CV} \leq 20 \%$; high when $20 \%<\mathrm{C}$.V. $\leq 30 \%$; and very high when C.V. > 30\% (PIMENTEL-GOMES \& GARCIA, 2002).

To help compare the distribution values of each nutrient, it was proposed the nutritional sufficiency index - NSI (\%):

$$
\mathrm{NSI}=\frac{\mathrm{OBS}}{\mathrm{LIM}_{\mathrm{INF}}} 100
$$

where,

OBS - observed nutrient content, and

$\mathrm{LIM}_{\mathrm{INF}}$ - lower limit of the 'high' range for the nutrient. This value is frequently defined by soil scientists.

A multiple regression model was developed for yield as a function of chemical attributes of soil and plant characteristics. The best subset variable selection method was used. A 0.05 significance value for the $\mathrm{F}$ distribution was used to control entering and removal the effects. The adjusted multiple coefficient of determination ( $\mathrm{R}^{2}$ adjusted) was used as selection criterion for the best model for the specified effects. After an exploratory analysis, the decision was to fit the data to the following model:

$$
\begin{aligned}
& \mathrm{Pro}=\mathrm{a}+\mathrm{bP}+\mathrm{c} \mathrm{P}^{2}+\mathrm{d} \mathrm{K}+\mathrm{eK}^{2}+\mathrm{f} \mathrm{pH}+\mathrm{gpH}^{2}+\mathrm{hCu}+\mathrm{iCu} \mathrm{Cu}^{2}+\mathrm{jFe}+\mathrm{kFe}^{2}+ \\
& 1 \mathrm{Mn}+\mathrm{n} \mathrm{Mn}^{2}+\mathrm{mSat}+\mathrm{nSat}^{2}+\mathrm{oLeng}+\mathrm{pLeng}^{2}+\mathrm{qDiam}+\mathrm{rDiam}{ }^{2}+\varepsilon
\end{aligned}
$$

where,

Pr - response variable: yield, $\mathrm{kg} \mathrm{ha}^{-1}$;

$\mathrm{P}, \mathrm{K}, \mathrm{pH}, \mathrm{Cu}, \mathrm{Fe}, \mathrm{Mn}$ and Sat - soil attributes;

Leng - fruit length;

Diam - fruit diameter;

a, b ... r - model parameters to be estimated by least squares method, and

$\varepsilon$ - random error.

\section{RESULTS AND DISCUSSION}

The computed attributes (table 1) showed a range of variability, including low (pH, length and diameter of fruit), medium $(\mathrm{Mg}$ and $\mathrm{C})$, high $(\mathrm{Ca}$ and $\mathrm{Cu})$ and very high $(\mathrm{P}, \mathrm{K}, \mathrm{Zn}, \mathrm{Fe}, \mathrm{Mn}$ and 
yield) (PIMENTEL-GOMES \& GARCIA, 2002). Several attributes were normally distributed (P, $\mathrm{K}, \mathrm{Ca}, \mathrm{Mg}, \mathrm{C}, \mathrm{Mn}$ and length of fruit), but the others were not $(\mathrm{pH}, \mathrm{Cu}, \mathrm{Zn}, \mathrm{Fe}$, diameter of fruit and yield).

TABLE 1. Descriptive analysis of soil and plant attributes.

\begin{tabular}{|c|c|c|c|c|c|c|c|c|}
\hline Atributes & $\begin{array}{c}\mathrm{N}^{\circ} \text { of } \\
\text { samples }\end{array}$ & Minimum & Average & Median & Maximum & $\begin{array}{c}\text { Standard } \\
\text { deviation }\end{array}$ & $\mathrm{CV}$ & Normality \\
\hline $\mathrm{P}$ content $\left(\mathrm{mg} \mathrm{dm}^{-3}\right)$ & 18 & 2.8 & 4.9 & 4.6 & 9.0 & 1.6 & 32.8 & yes \\
\hline $\mathrm{K}$ content $\left(\mathrm{cmolc} \mathrm{dm}^{-3}\right)$ & 18 & 0.19 & 0.46 & 0.41 & 0.99 & 0.21 & 45.5 & yes \\
\hline Ca content $\left(\mathrm{cmolc} \mathrm{dm}^{-3}\right)$ & 18 & 3.52 & 6.41 & 6.28 & 9.14 & 1.6 & 24.9 & yes \\
\hline Mg content $\left(\mathrm{cmolc} \mathrm{dm}^{-3}\right)$ & 18 & 1.67 & 2.55 & 2.65 & 3.26 & 0.46 & 18 & yes \\
\hline $\mathrm{pH}$ & 18 & 4.6 & 5.1 & 5.0 & 5.5 & 0.3 & 5.8 & no \\
\hline $\mathrm{C}$ content $\left(\mathrm{g} \mathrm{dm}^{-3}\right)$ & 18 & 20.44 & 28.16 & 28.74 & 33.56 & 3.16 & 11.2 & yes \\
\hline Cu content $\left(\mathrm{mg} \mathrm{dm}^{-3}\right)$ & 18 & 7.00 & 9.38 & 9.05 & 14.1 & 2.1 & 22.4 & no \\
\hline $\mathrm{Zn}$ content $\left(\mathrm{mg} \mathrm{dm}^{-3}\right)$ & 18 & 2.00 & 4.42 & 3.85 & 9.7 & 2.0 & 44.5 & no \\
\hline $\mathrm{Fe}\left(\mathrm{mg} \mathrm{dm}^{-3}\right)$ & 18 & 34.0 & 55.3 & 48.0 & 150.0 & 28.6 & 51.7 & no \\
\hline Base saturation $(\%)$ & 18 & 70.0 & 164.8 & 155.0 & 350.0 & 73.7 & 44.7 & yes \\
\hline Mn contet $\left(\mathrm{mg} \mathrm{dm}^{-3}\right)$ & 18 & 45.50 & 66.29 & 71.35 & 80.5 & 10.68 & 16.1 & yes \\
\hline Length $(\mathrm{cm})$ & 36 & 66.8 & 82.2 & 81.9 & 94.8 & 5.8 & 7 & yes \\
\hline Diameter $(\mathrm{cm})$ & 36 & 58.8 & 69.4 & 68.4 & 90.8 & 5.1 & 7.4 & no \\
\hline Yield $\left(\mathrm{kg} \mathrm{ha}^{-1}\right)$ & 36 & 57 & 693 & 494 & 2337 & 538 & 77.6 & no \\
\hline
\end{tabular}

Soil attributes were in the range: very low $(\mathrm{K})$, low $(\mathrm{P}, \mathrm{K}$, and base saturation), medium $(\mathrm{P}, \mathrm{K}$, $\mathrm{Ca}, \mathrm{Fe}$, and base saturation), and high (all attributes), according to the interpretation levels (table 2) suggested by COMISSÃO DE FERTILIDADE DO SOLO (1994). All attributes were at levels of nutrient availability sufficient for plant development, except that $28 \%$ of the area was lacking in $\mathrm{P}$ and $83 \%$ in $\mathrm{K}$.

TABLE 2. Interpretation levels of soil chemical attributes with the percentage found in each range

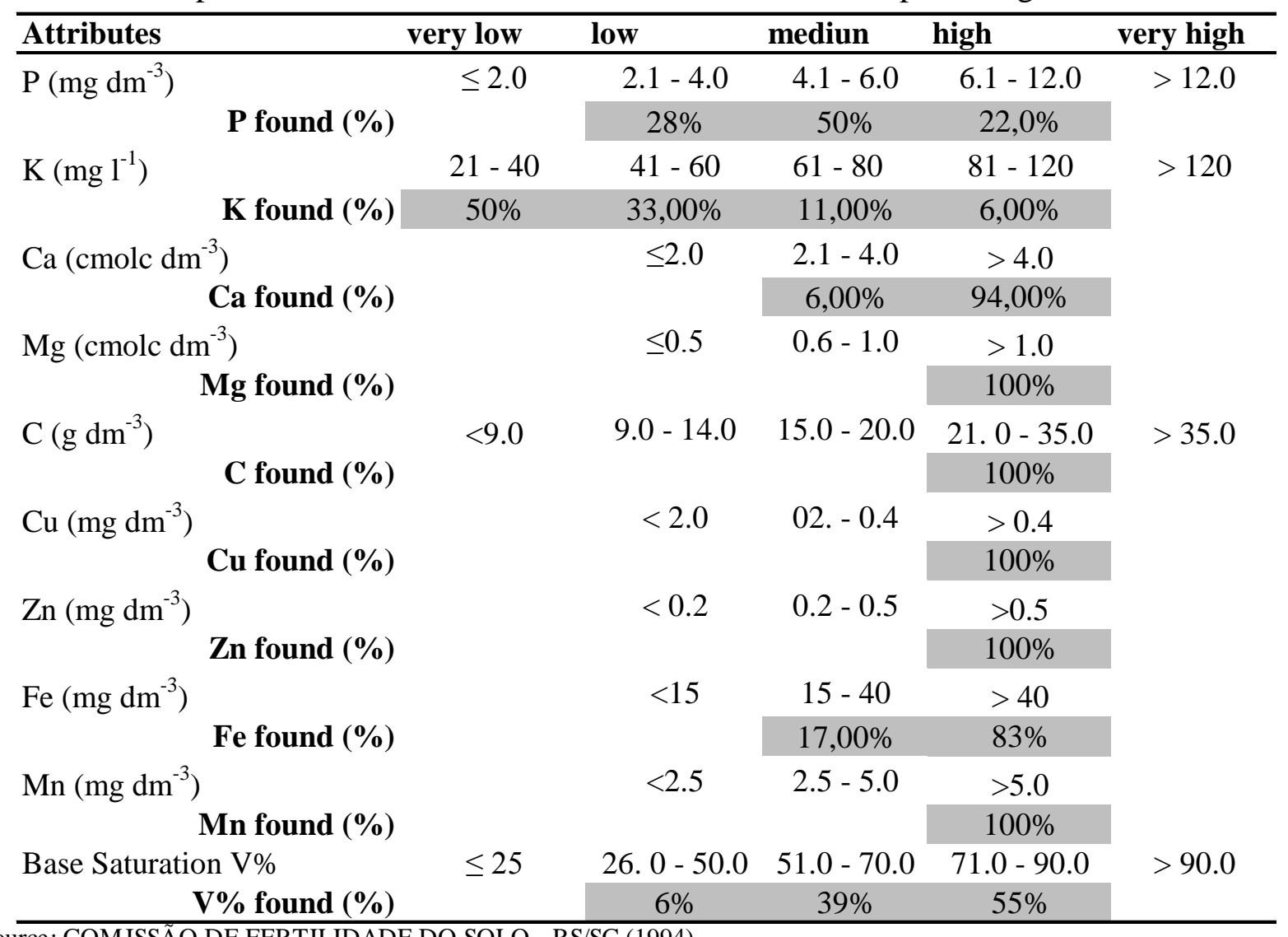


On average, the spatial variability characterized by the $S V I$ increased with the range $(\mathrm{m})$ (Figure 3 ). The $\mathrm{R}^{2}$ was not good but the linear coefficient was significative at 0.05 significance value for the $\mathrm{F}$ test.



FIGURE 3. Spatial variability index (SVI, \%) as function of the range (m).

The C.V. (Figure 4) also increased with the SVI, and but the $\mathrm{R}^{2}$ was low and the linear coefficient was not significative at 0.05 significance value for the $\mathrm{F}$ test. This fact should be investigated more carefully during the next years in order to have definitive conclusions.

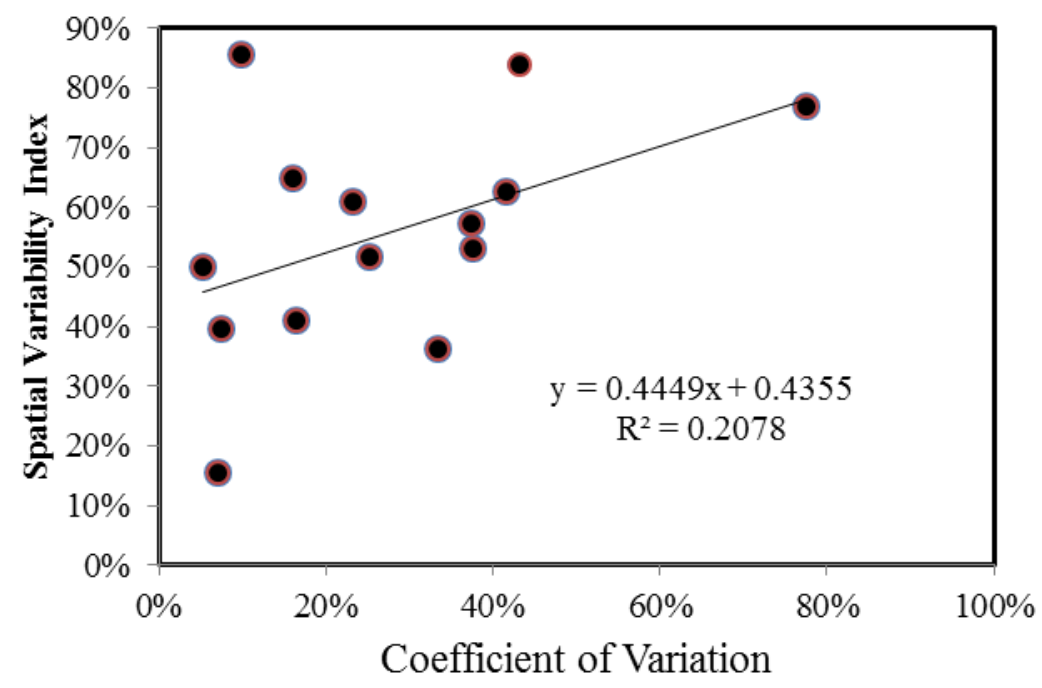

FIGURE 4. Spatial variability index $(S V I, \%)$ as a function of the coefficient of variation (C.V., \%).

The proposed nutritional sufficiency index (NSI, \%) of soil attributes was displayed in boxplots (Figure 5). In this index, the 100\% figure represents the lower value of the "high level" range of each attribute, which was herein considered the ideal level. The attributes were ordered from left to right, according to their increasing nutritional sufficiency. Special attention should be given to $\mathrm{Zn}, \mathrm{P}, \mathrm{V} \%$ and $\mathrm{Fe}$, since part of the samples concerning each attribute showed lower responses when compared to the optimum level. Attention should also be given to excess macro and micronutrients due to a possible occurrence of toxic action and interference with other nutrients. A classic example is the negative interaction between P and Zn (PERES, 2002) and the toxic action of some excess micronutrients (VALLADARES et al., 2007). 


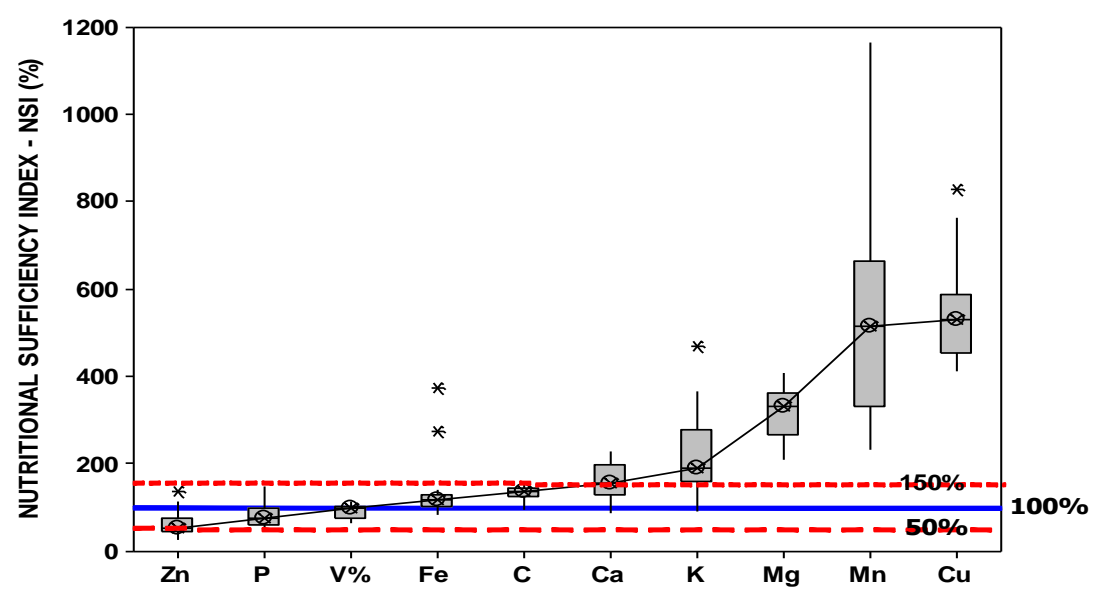

FIGURE 5. Box-plot of the nutritional sufficiency index (NSI, \%) of the soil attributes.

Pear yield had low linear correlation with $\mathrm{P}$ and $\mathrm{K}$ (Table 3), i.e., less than $12 \%\left(\mathrm{R}^{2}=0.12\right.$; $\mathrm{R}=0.35$ ) of the yield variability was explained by these attributes. Furthermore, this correlation was lower for the remaining soil attributes. This low correlation probably occurred because all soil attributes were at least at a medium level of fertility, with the exception of $\mathrm{P}$, which was low in $17 \%$ of the area. Fruit diameter explained $27 \%$ of yield variability $\left(\mathrm{R}^{2}=0.27 ; \mathrm{R}=0.52\right)$. Within the set, the most closely correlated attributes were: $\mathrm{Ca}$ and $\mathrm{Mg}(\mathrm{R}=0.86) ; \mathrm{Ca}$ and $\mathrm{pH}(\mathrm{R}=0.86) ; \mathrm{Mg}$ and $\mathrm{pH}$ $(\mathrm{R}=0.89)$; base saturation and $\mathrm{Ca}(\mathrm{R}=0.88)$; base saturation and $\mathrm{pH}(\mathrm{R}=0.89)$.

TABLE 3. Pearson linear corre lation coefficients (R) for pear yield data and for soil and plant attributes.

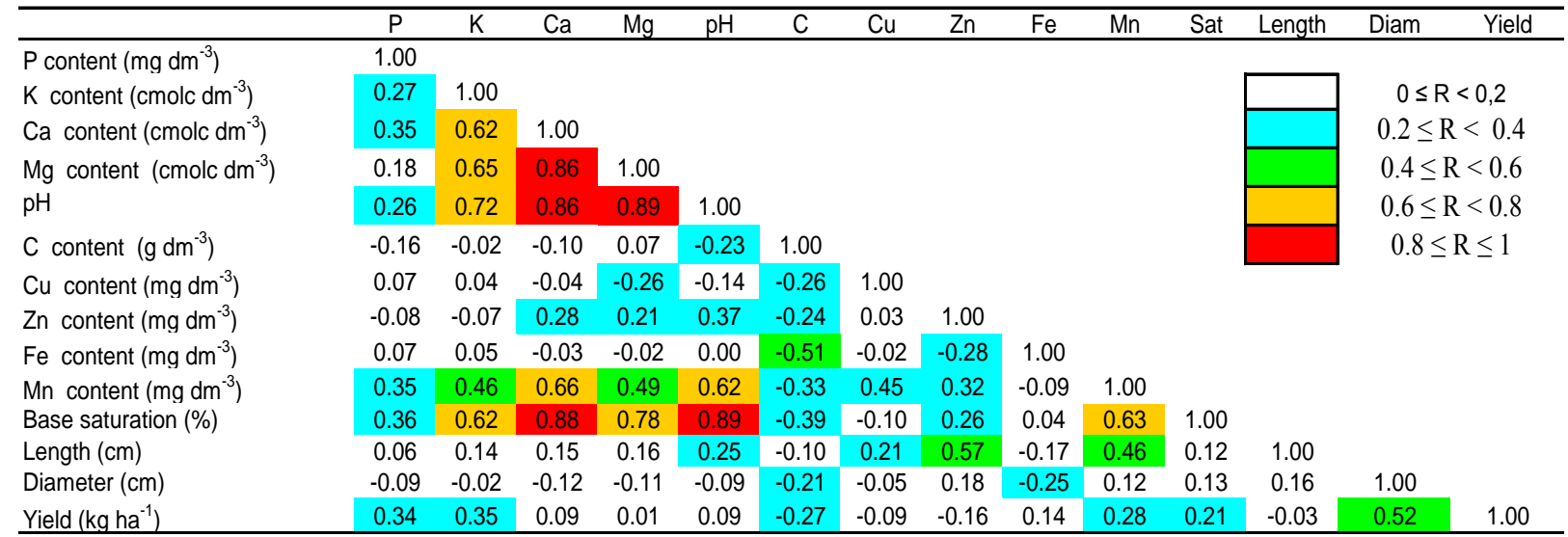

Non-parametric correlation results were similar to those found for Pearson linear correlation (table 4). For yield, the highest values were found for $\mathrm{K}(\mathrm{RS}=0.40), \mathrm{C}(\mathrm{RS}=0.49)$, base saturation $(\mathrm{RS}=0.42)$ and fruit diameter $(\mathrm{RS}=0.35)$.

TABLE 4. Spearman rank-order correlation coefficients $\left(\mathrm{R}_{\mathrm{S}}\right)$ for pear yield data, soil and plant attributes.

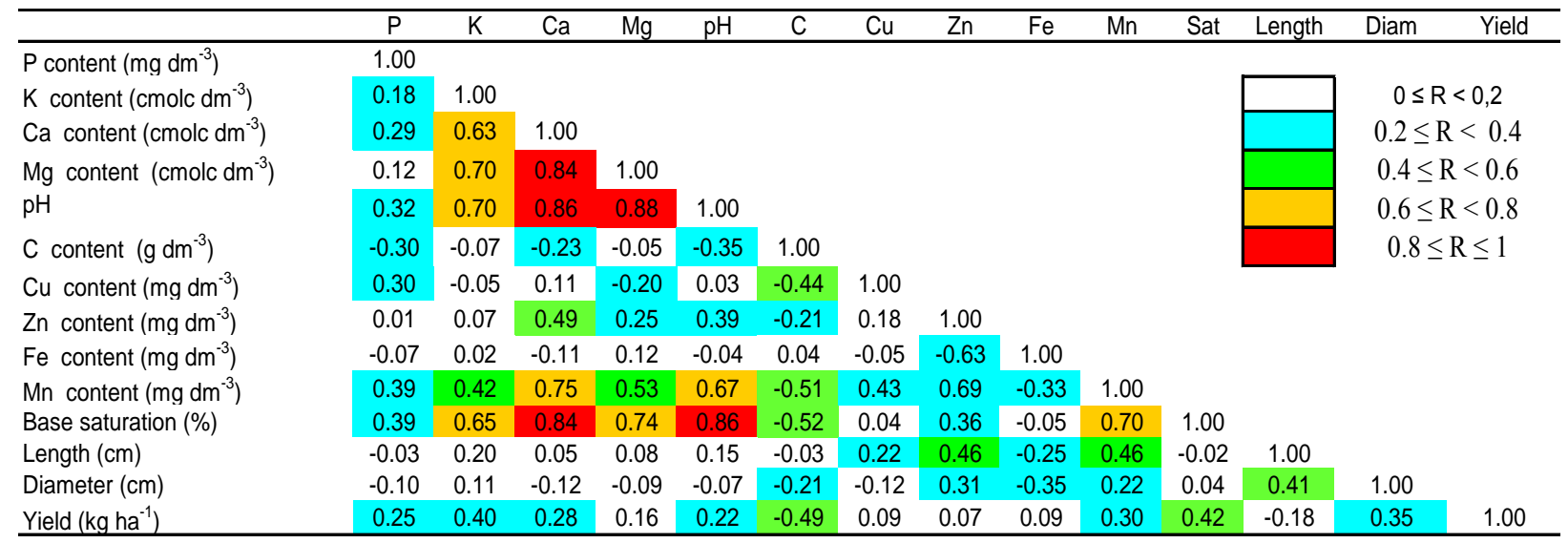


The models for the experimental semivariograms (Table 5, Figure 6) were: spherical (K, pH, $\mathrm{C}, \mathrm{Zn}$, length and fruit diameter); exponential (P); and Gaussian $(\mathrm{Ca}, \mathrm{Mg}, \mathrm{Cu}, \mathrm{Fe}, \mathrm{Mn}$, base saturation and yield).

TABLE 5. Models and parameters of the semivariograms for the computed variables.

\begin{tabular}{|c|c|c|c|c|c|c|}
\hline Variable & Model & $\begin{array}{l}\text { Nugget Effect } \\
\text { (Co) }\end{array}$ & $\begin{array}{l}\text { Partial Sill } \\
\text { (C1) }\end{array}$ & $\begin{array}{c}\text { Sill } \\
(\mathrm{Co}+\mathrm{C} 1)\end{array}$ & $\begin{array}{l}\text { Range } \\
\mathrm{a}(\mathrm{m})\end{array}$ & $\begin{array}{c}\text { Spatial Variability Index } \\
\text { SVI }\end{array}$ \\
\hline P content $\left(\mathrm{mg} \mathrm{dm}^{-3}\right)$ & Exponential & 1.64 & 0.93 & 2.57 & 250.4 & $36.2 \%$ \\
\hline $\mathrm{K}$ content $\left(\mathrm{cmolc} \mathrm{dm}^{-3}\right)$ & Spherical & 0.03 & 0.05 & 0.08 & 186.5 & $62.5 \%$ \\
\hline Ca content $\left(\mathrm{cmolc} \mathrm{dm}^{-3}\right)$ & Gaussian & 1.15 & 1.80 & 2.95 & 196.4 & $61.0 \%$ \\
\hline $\mathrm{Mg}$ content $\left(\mathrm{cmolc} \mathrm{dm}^{-3}\right)$ & Gaussian & 0.13 & 0.09 & 0.22 & 206.2 & $40.9 \%$ \\
\hline $\mathrm{pH}$ & Spherical & 0.04 & 0.04 & 0.08 & 176.7 & $50.0 \%$ \\
\hline C content $\left(\mathrm{g} \mathrm{dm}^{-3}\right)$ & Spherical & 1.12 & 6.72 & 7.84 & 122.7 & $85.7 \%$ \\
\hline $\mathrm{Cu}$ content $\left(\mathrm{mg} \mathrm{dm} \mathrm{m}^{-3}\right)$ & Gaussian & 2.18 & 2.32 & 4.50 & 103.0 & $51.6 \%$ \\
\hline $\mathrm{Zn}$ content $\left(\mathrm{mg} \mathrm{dm} \mathrm{m}^{-3}\right)$ & Spherical & 0.96 & 1.09 & 2.05 & 216.0 & $53.2 \%$ \\
\hline Fe content $\left(\mathrm{mg} \mathrm{dm}^{-3}\right)$ & Gaussian & 92.55 & 124.21 & 216.76 & 127.6 & $57.3 \%$ \\
\hline Mn content $\left(\mathrm{mg} \mathrm{dm}^{-3}\right)$ & Gaussian & 1464.7 & 7689.7 & 9154.4 & 216.0 & $84.0 \%$ \\
\hline Base Saturation (\%) & Gaussian & 29.70 & 55.17 & 84.87 & 240.5 & $65.0 \%$ \\
\hline Length $(\mathrm{cm})$ & Spherical & 24.54 & 4.49 & 29.03 & 13.4 & $15.5 \%$ \\
\hline Diameter $(\mathrm{cm})$ & Spherical & 15.98 & 10.54 & 26.52 & 91.1 & $39.7 \%$ \\
\hline Yield $\left(\mathrm{kg} \mathrm{ha}^{-1}\right)$ & Gaussian & 42437 & 142000 & 184437 & 168.8 & $77.0 \%$ \\
\hline
\end{tabular}

The data were all spatially dependent, ranging from very low (fruit length) to low (P, fruit diameter), medium ( $\mathrm{Mg}, \mathrm{pH}, \mathrm{Cu}, \mathrm{Zn}, \mathrm{Fe})$, high (Ca, K, saturation of bases and yield), and very high (Mn and C), according to the spatial variability index (SVI, \%) (Figure 7). According to CAMBARDELLA et al. (1994), the attributes that present a strong spatial dependence are more influenced by intrinsic soil properties, such as texture and mineralogy. On the other hand, those that present a weak dependence are more influenced by external factors, such as fertilizer applications and soil tillage.

The thematic maps (Figure 8) built by ordinary Kriging show that, for each variable, minimum and maximum values were found in different locations, in accordance with the low correlation registered among the variables. The lowest yield was found at the east side of the area, indicating the need of further investigation for determining limiting factors such as soil depth and compaction, management history, drainage problems, and occurrence of pests, diseases and weeds.



(a) phosphorus (P)

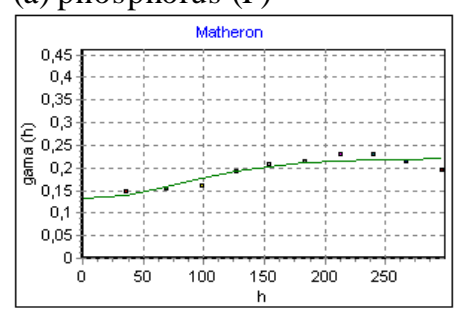

(d) magnesium $(\mathrm{Mg})$

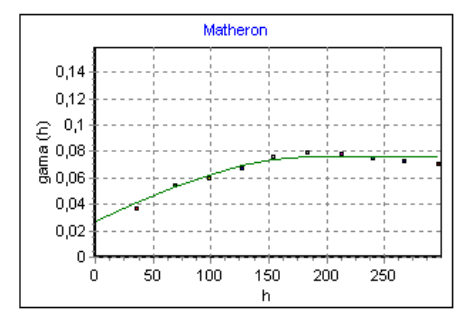

(b) potassium (K)

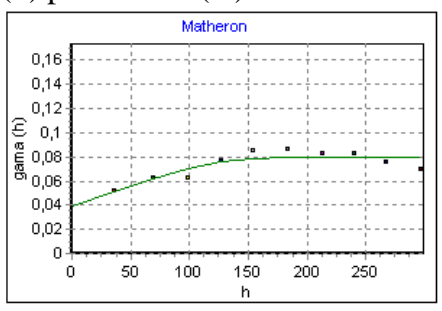

(e) $\mathrm{pH}$

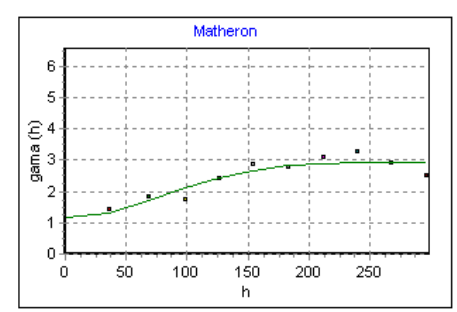

(c) calcium $(\mathrm{Ca})$

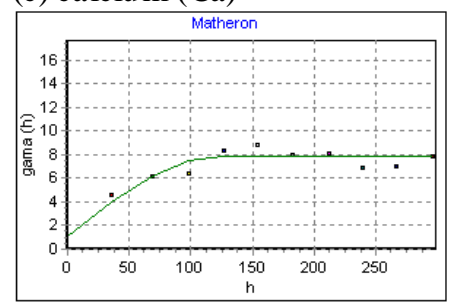

(f) carbon (C) 


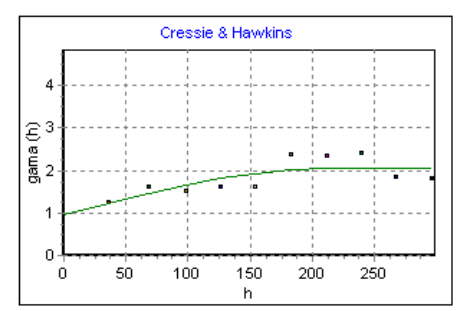

(g) zinc ( $\mathrm{Zn})$

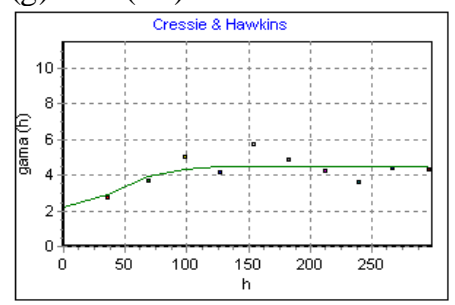

(j) copper $(\mathrm{Cu})$

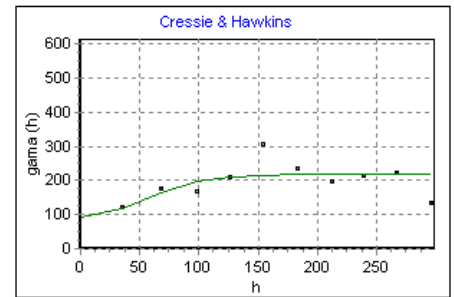

(h) iron $(\mathrm{Fe})$



(1) fruit length

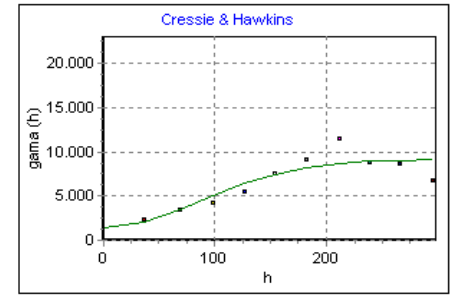

(i) manganese $(\mathrm{Mn})$

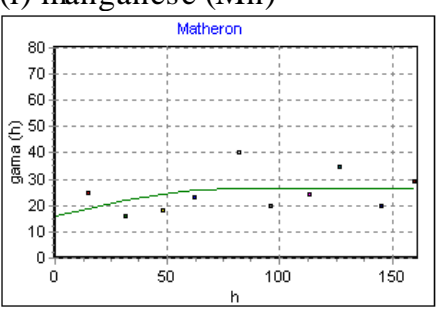

(m) fru it diameter

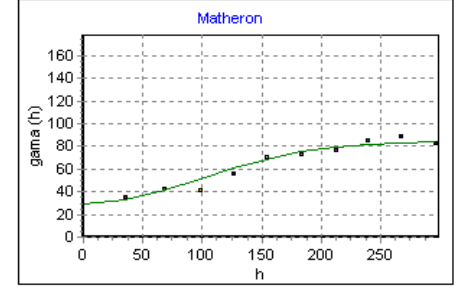

(n) base saturation



(o) yield

FIGURE 6. Semivariograms for the analyzed variables.

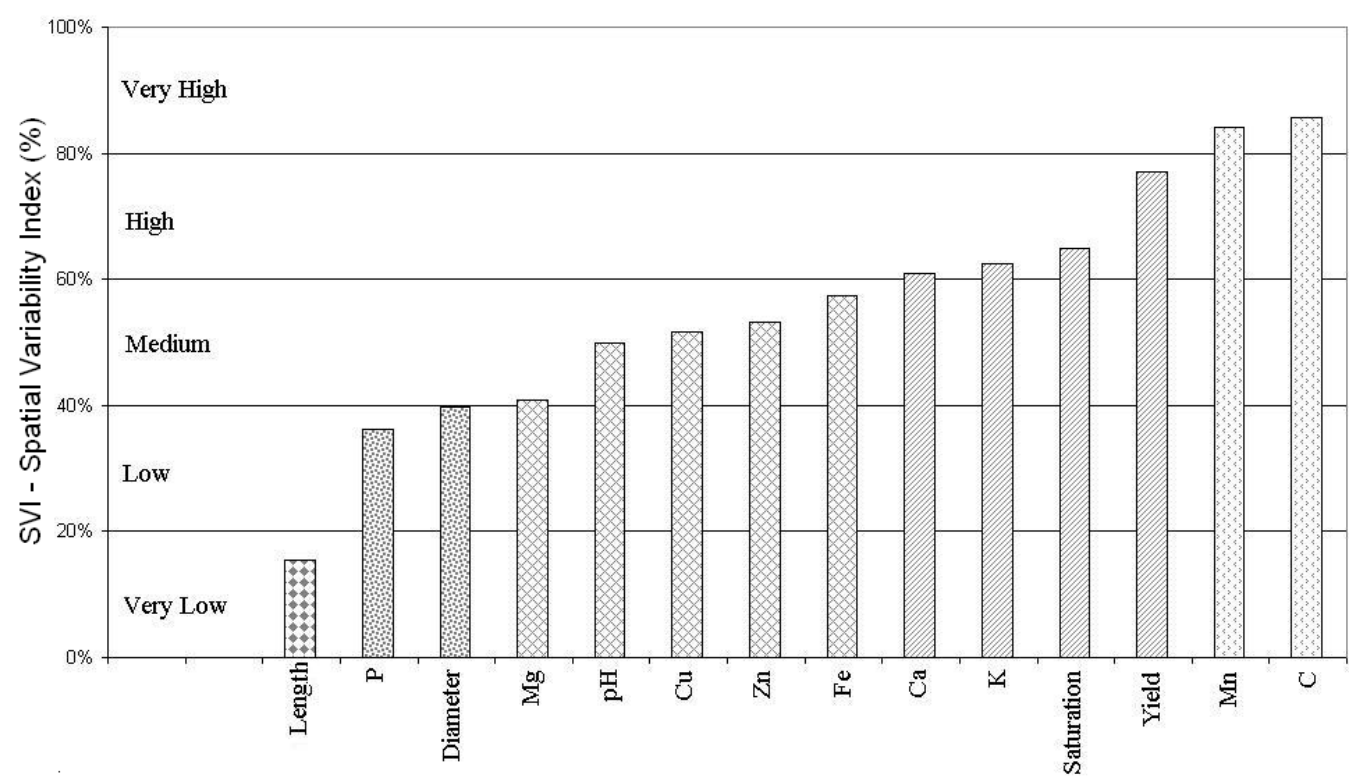

FIGURE 7. Spatial variability index for each of the variables.

Models were developed to describe the influence of soil and plant attributes on pear trees yield (Prod, $\mathrm{kg} \mathrm{ha}^{-1}$ ) (table 6). Such models allowed an explanation of $54 \%\left(\mathrm{R}^{2}=0.54\right)$ of yield variability, when only soil attributes were considered, and $90 \%\left(\mathrm{R}^{2}=0.90\right)$, when fruit length and diameter were included. The model fit is presented in figure 9. 


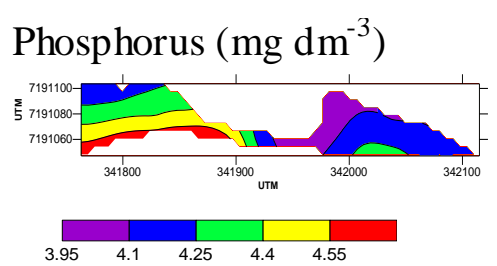

Magnesium (cmolc dm $\left.{ }^{-3}\right)$
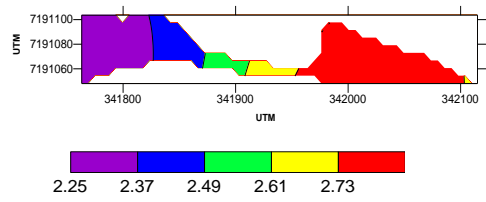

Carbon $\left(\mathrm{g} \mathrm{dm}^{-3}\right)$


Copper $\left(\mathrm{mg} \mathrm{dm}^{-3}\right)$
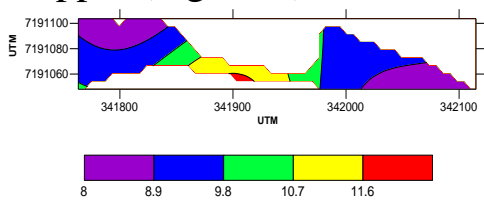

Diameter $(\mathrm{cm})$

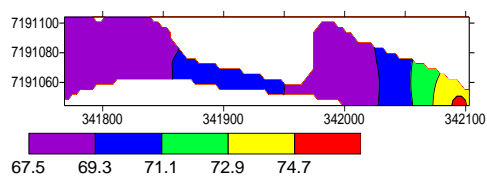

Potassium (cmolc dm $\mathrm{dm}^{-3}$

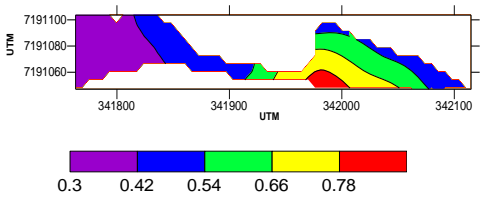

Zinc $\left(\mathrm{mg} \mathrm{dm}^{-3}\right)$
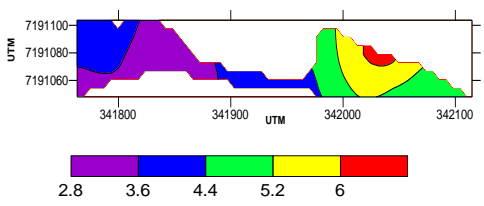

Manganese $\left(\mathrm{mg} \mathrm{dm}^{-3}\right)$

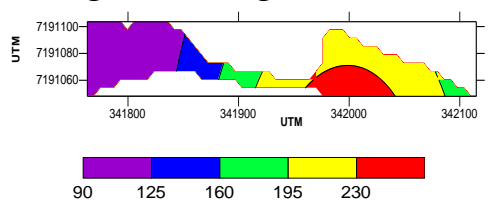

Base saturation $(\%)$
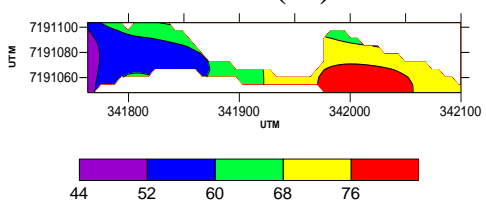

Yield $\left(\mathrm{kg} \mathrm{ha}^{-1}\right)$



Calcium (cmolc dm $\left.{ }^{-3}\right)$

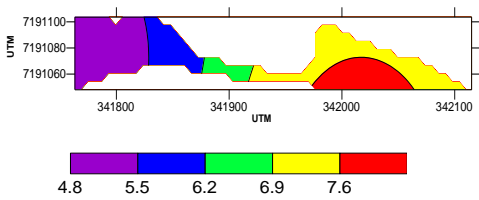

Iron $\left(\mathrm{mg} \mathrm{dm}^{-3}\right)$

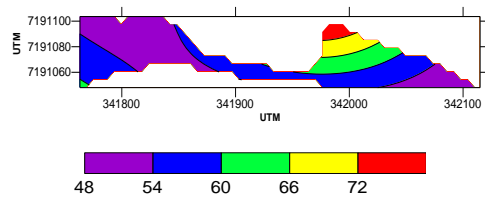

$\mathrm{pH}$

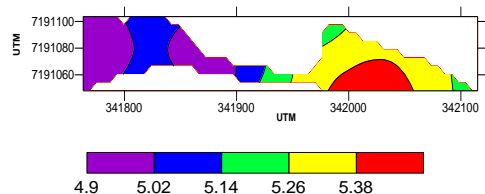

Length $(\mathrm{cm})$


FIGURE 8. Thematic maps of computed variables.

TABLE 6. Adjustment equations and multiple coefficient of determination for pear trees yield (Prod, $\mathrm{kg} \mathrm{ha}^{-1}$ ).

\begin{tabular}{|c|c|c|c|c|c|c|c|c|c|c|c|c|}
\hline Model & Constant & $\mathrm{P}^{2}$ & K & $\mathrm{K}^{2}$ & $\mathrm{Cu}^{2}$ & $\mathrm{Fe}$ & $\mathrm{Mn}$ & $\mathrm{Sat}^{2}$ & Comp $^{2}$ & Diam & $\mathrm{pH}$ & $\mathrm{R}^{2}$ \\
\hline 1 & 105554 & & 19752 & & -91.9 & & 71.2 & & & & -21981.5 & 0.54 \\
\hline 2 & -36124 & 85.6 & 71448 & -52945 & -52.3 & 119 & 49.3 & -3.4 & -1.8 & 541.9 & & 0.90 \\
\hline
\end{tabular}

All estimators were significant according to t test at 0.05 significance level.
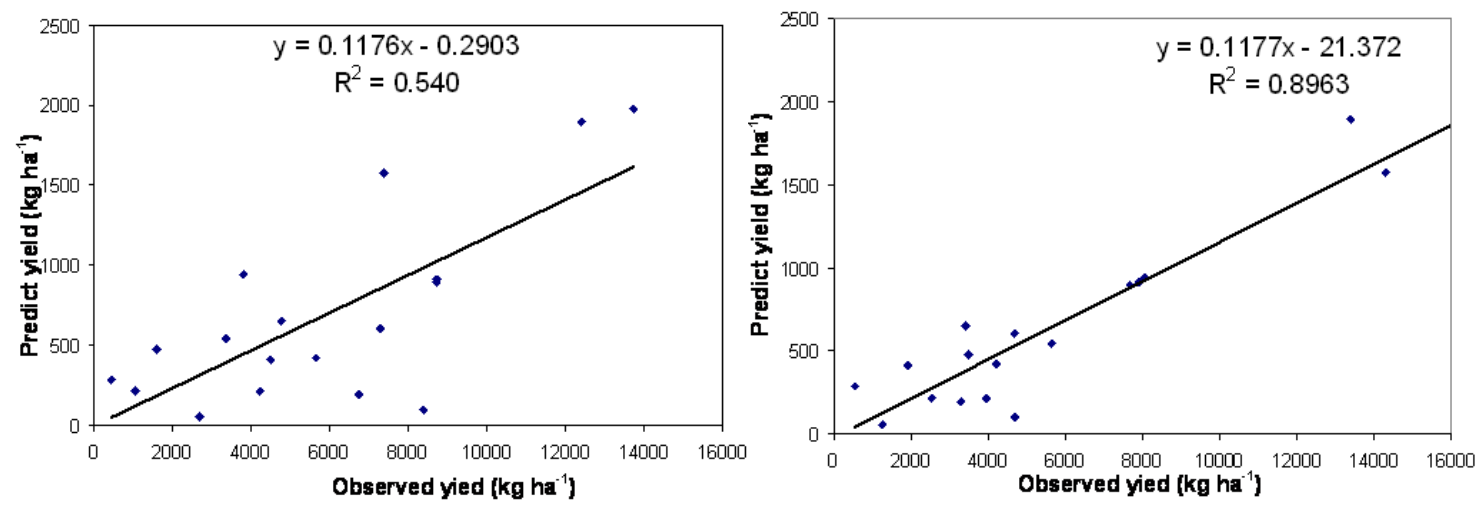

FIGURE 9. Predicted yield as a function of the observed yield for model 1 (left) and model 2 (right). 


\section{CONCLUSION}

The yield of pear trees had low linear correlation with the measured attributes $(\mathrm{P}, \mathrm{K}, \mathrm{Ca}, \mathrm{Mg}$, $\mathrm{Al}_{3+}, \mathrm{pH}, \mathrm{CaCl}_{2}, \mathrm{C}, \mathrm{Cu}, \mathrm{Zn}, \mathrm{Fe}, \mathrm{Mn}$, base saturation, length and diameter of fruits).

The variability of the measured attributes was considered very low $(\mathrm{K})$, low $(\mathrm{P}, \mathrm{K}$, and base saturation), medium (P, K, Ca, Fe, and base saturation), and high (all attributes), according to the coefficient of variation.

Spatial dependence levels were found to be very low (fruit length), low ( $\mathrm{P}$, diameter of fruit), medium ( $\mathrm{Mg}, \mathrm{pH}, \mathrm{Cu}, \mathrm{Zn}, \mathrm{Fe}$ ), high (Ca, K, saturation of bases and yield), and very high (Mn and $\mathrm{C})$, according to the spatial variability index that was proposed in this work.

\section{ACKNOWLEDGEMENTS}

The authors thank the support provided by the State University of Western Paraná (Unioeste), the Araucária Foundation (Fundação Araucária), the General office of State of Science, Technology and Higher Education - SETI/PR, the Coordination for the Improvement of Higher Level Personnel (CAPES - Coordenação de Aperfeiçoamento de Pessoal de Nível Superior), the National Council for Scientific and Technological Development $(\mathrm{CNPq}$ - Conselho Nacional de Desenvolvimento Científico e Tecnológico), and the Government of the State of Paraná.

\section{REFERENCES}

AGGELOPOULOU, A.D., BOCHTIS, D.; FOUNTAS, S.; SWAIN, K.C.; GEMTOS, T.A.; NANOS, G.D. Yield prediction in apple orchards based on image processing. Precision Agriculture. Dordrecht, 2010a. Disponível em: <http://www.springerlink.com/content/n671072m3474vvq1/>. Acesso em: 20 jan. 2011.

AGGELOPOUlOU, K.D.; PATERAS, D.; FOUNTAS, S.; GEMTOS, T.A.; NANOS, G.D. Soil spatial variability and site-specific fertilization maps in an apple orchard. Precision Agriculture. Dordrecht, 2010b. Disponível em: <http://www.springerlink.com/content/23786817wj83u041/>. Acesso em: 20 jan. 2011.

AGGELOPOULOU, K.D.; WULFSOHN, D.; FOUNTAS, S.; GEMTOS, T.A.; NANOS, G.D.; BLACKMORE, S. Spatial variation in yield and quality in a small apple orchard. Precision Agriculture, Dordrecht, v.11, n.5, p.538-556, 2010c.

CALDERÓN, C.A.V.; MARTÍNEZ, L.J.M.; HENAO, R.G.Variabilidad espacial del suelo y su relacion con el rendimiento de mango (Mangifera indica L.). Revista Brasileira de Fruticultura, Jaboticabal, v.30, n.4, p.1146-1151, dez. 2008.

CAMBARDELLA, C.A.; MOORMAN, T.B.; NOVAK, J.M.; PARKIN, T.B.; KARLEN, D.L.; TURCO, R.F.; KONOPKA, A.E. Field-scale variability of soil properties in central Iowa soils. Soil Science Society of America Journal, Madison, v.58, n.5, p.1501-1511, 1994.

COMISSÃO DE FERTILIDADE DO SOLO - RS/SC. Recomendações de adubação e calagem para os estados do Rio Grande do Sul e Santa Catarina. 3.ed. Passo Fundo: SBCS - Núcleo Regional Sul/ EMBRAPA/CNPT, 1994. 224 p.

EMBRAPA - EMPRES A BRASILEIRA DE PESQUIS A AGROPECUÁRIA. Serviço Nacional de Levantamento e Conservação de Solos. Sistema Brasileiro de classificação de solos. Brasília: Embrapa Produção de Informação, 1999. 412 p.

FACHINELLO, J.C.; NACHTIGAL, J. C.; KERSTEN, E. Fruticultura: fundamentos e práticas. Pelotas: Embrapa Clima Temperado, 2008. 311 p.

FARIAS, P.R.S.; NOCITI, L.A.S.; BARBOSA, J.C.; PERECIN, D. Agricultura de precisão: mapeamento de produtividade em pomares cítricos usando geoe statística. Revista Brasileira de Fruticultura, Jaboticabal, v.25, n.2, p.235-241, ago. 2003. 
FIORAVANÇO, J.C. A cultura da pereira no Brasil: situação econômica e entraves para o seu crescimento. Informações Econômicas, São Paulo, v.37, n.3, p.52-60, mar. 2007.

LEÃO, M.G.A.; MARQUES JÚNIOR, J.; SOUZA, Z.M.; SIQUEIRA, D.S.; PEREIRA, G.T. O relevo na interpretação da variabilidade espacial dos teores de nutrientes em folha de citros. Revista Brasileira de Engenharia Agrícola e Ambiental, Campina Grande, v.14, n.11, p.1152-1159, nov. 2010.

MIRANDA, N.O.; OLIVEIRA, T.S.; LEVIEN, S.L.A.; SOUZA, E.R. Variabilidade espacial da qualidade de frutos de melão em áreas fertirrigadas. Horticultura Brasileira, Brasília, v.23, n.2, p. 242-249, abr-jun. 2005.

MOLIN, J.P; MASCARIN, L.S. Colheita de citros e obtenção de dados para mapeamento da produtividade. Revista Engenharia Agrícola, Jaboticabal, v.27, n.1, p.259-266, jan-abr. 2007.

PERES, L. E. P. Nutrição mineral. 2002. Disponível em:

www.biologia.ufc.br/backup/docentes/JoaoLuiz/Nutricao.Mineral.de.Plantas.pdf

NutricaoMineral.pdf $>$ Acesso em: 15 jan. 2011.

PERRY, E.M.; DEZZANI, R.J.; SEAVERT, C.F.; PIERCE, F.J. Spatial variation in tree characteristics and yield in a pear orchard. Precision Agriculture, Dordrecht, v.11, n.1, p.42-60, 2009.

PIMENTEL-GOMES, F.; GARCIA, C.H. 2002. Estatística aplicada a experimentos agronômicos e florestais. Piracicaba: FEALQ, 2002. 309 p.

SILVA, F.M.; SOUZA, Z.M.; FIGUEIREDO, C.A.P.; MARQUES JÚNIOR, J.; MACHADO, R.V. Variabilidade espacial de atributos químicos e de produtividade na cultura do café. Ciência Rural, Santa Maria, v.37, n.2, p.401-407, mar-abr. 2007.

SIQUEIRA, D.S.; MARQUES JÚNIOR, J.; PEREIRA, G. T. The use of landforms to predict the variability of soil and orange attributes. Geoderma, Amsterdam, v.155, n.1-2, p.55-66, 2010.

TISSEYRE, B.; MCBRATNEY, A.B. A technical opportunity index based on mathematical morphology for site-specific management: an application to viticulture. Precision Agriculture, Dordrecht, v.9, n.1-2, p.101-113, 2008.

VALLADARES, G.S.; CAMARGO, O.A.; AZEVEDO, E.C. ; SILVA, A.M.C. Variabilidade espacial e disponibilidade de zinco em solos de vinhedos e adjacências da região vitícola de Jundiaí, SP. In: SIMPÓSIO BRASILEIRO DE SENSORIAMENTO REMOTO, 13., 2007, Florianópolis. Anais... Florianópolis: INPE, 2007. p.449-456. 


\section{ERRATUM}

In the paper "SPATIAL VARIABILITY OF YIELD AND OTHER PARAMETERS ASSOCIATED WITH PEAR TREES", with DOI number: 10.1590/S0100-69162012000200018, published in the journal Agricultural Engineering 32 (2):381-392, on the page 381:

Where it reads:

MARCIA R. S. KONOPATZKI ${ }^{1}$, EDUARDO G. SOUZA ${ }^{2}$, LÚCIA H. P. NÓBREGA ${ }^{3}$, MIGUEL A. URIBE-OPAZO ${ }^{4}$, GRAZIELE SUSZEK ${ }^{5}$

It should read:

MARCIA R. S. KONOPATZKI ${ }^{1}$, EDUARDO G. SOUZA ${ }^{2}$, LÚCIA H. P. NÓBREGA ${ }^{3}$, MIGUEL A. URIBE-OPAZO ${ }^{4}$, GRAZIELI SUSZEK ${ }^{5}$ 